\title{
A review of the catalytic gasification of different algae in supercritical water (SCW)
}

\author{
Wenhan Song ${ }^{1, a}$, Shuzhong Wang ${ }^{1, *}$ and Yang Guo ${ }^{1}$ \\ ${ }^{1}$ Xi'an Jiaotong University, No.28 Xianning West Road, \\ Xi'an Shaanxi province, P.R. China \\ aswh8648@163.com
}

\begin{abstract}
Keywords: Catalytic gasification; Algae; Supercritical water
Abstract. Among various biomass, algae have unique advantages such as fast growing, high efficient photosynthesis, no competition with crops etc. Supercritical Water Gasification (SCWG) is a potential technology for converting algae biomass into gases (including $\mathrm{H}_{2}, \mathrm{CH}_{4}, \mathrm{CO}, \mathrm{CO}_{2}$ ), with merits with higher gas yield and lower tar and char etc. A review of the catalytic gasification of different algae in Supercritical Water (SCW) is presented here, summarizing the past research about the gas yield and distribution in production and their corresponding conditions and valuable conclusions for various algae. Finally, based on the literatures above-mentioned, future directions in this field are suggested.
\end{abstract}

\section{Introduction}

A brief introduction of algae biomass energy. With the development of world economy, more and more fuel is desired. However, traditional fossil fuels are non-renewable resource, pollute the environment and produce green gases during combustion process. Thus, it is necessary to seek an environmentally-friendly and renewable substitution for fossil fuels. Biomass is an ideal, renewable energy. Obtaining energy from biomass could help to relieve fossil energy crisis and would not increase $\mathrm{CO}_{2}$ content in air. Algae have properties of short cultivation cycle, high photosynthetic efficiency, high gas yield, which are considered as a promising substitution for addressing the energy crisis and environmental issues associated with fossil fuel use [1].

Supercritical water gasification (SCWG) reaction. For converting high-moisture biomass such as algae, conventional gasification technologies has low thermal efficiency due to the desire of water vaporized in feedstock, which results from the fact that conventional biomass gasification processes require a dry feedstock. The energy required exceeds the energy that is needed to dry the feedstock prior to gasification. Hence, the energy utilized to remove water from wet biomass feedstock is lost as water evaporates. Supercritical water gasification (SCWG) is considered as the most promising method. SCWG is defined as an reaction process by physical-chemical change under the condition of $\mathrm{Tc} \geq 647 \mathrm{~K}$ and $\mathrm{Pc} \geq 22.1 \mathrm{MPa}$. In supercritical water, water is miscible with small organic compounds and gases [2], so a homogeneous phase reaction could exist at SCWG conditions after the solid biomass particles decompose and dissolve. In addition, SCWG process results in high gas yield and low yields of tar and char [3]. More importantly, the process of SCWG is with no need for drying feedstock, which reduces energy consuming during operating process. Due to advantages above-mentioned, SCWG technology for converting algae into gases like $\mathrm{H}_{2}, \mathrm{CH}_{4}, \mathrm{CO}, \mathrm{CO}_{2}$ has potential development prospects.

The research on SCWG of algae started from Antal in 1990. With more and more desire of renewable energy, more researchers have focused on it. Although there are not many research about it, they performed experiments about SCWG of different algae and obtained several valuable results. 


\section{SCWG of different algae species}

At present, the research on SCWG of algae primarily focused on Spirulina, Chlorella, Nannochloropsis and others such as Saccharina latissima, Phaeodactylum tricornutum, Scendesmus quadricauda.

Spirulina. Spirulina is a kind of common algae with high proteins and carbohydrates [4], which is often considered as healthy food boosting the body's defenses. In addition, it has also potential application in SCWG. Onwudili et al [5] provided a comparison of SCWG $\left(500{ }^{\circ} \mathrm{C}, 30\right.$ min reaction time, $36 \mathrm{MPa}, 15 \mathrm{wt} \%$ feedstock concentration) among Spirulina platensis, Chlorella vulgaris and Saccharina latissima in the presence/absence of $\mathrm{NaOH}$ and/or $\mathrm{Ni} / \mathrm{Al}_{2} \mathrm{O}_{3}$ and obtained that the gas yield of feedstock was $69 \%$ without $\mathrm{NaOH}$ and $\mathrm{Ni} / \mathrm{Al}_{2} \mathrm{O}_{3}$. When $\mathrm{NaOH}$ was used, water-soluble products were the predominant reaction products and the gas yield was $23 \%$ and $20 \%$ with only $\mathrm{NaOH}$ and $\mathrm{NaOH}$ and $\mathrm{Ni} / \mathrm{Al}_{2} \mathrm{O}_{3}$, respectively. Moreover, composition of gases yielded was different with or without $\mathrm{NaOH}$ and/or $\mathrm{Ni} / \mathrm{Al}_{2} \mathrm{O}_{3}$. $\mathrm{NaOH}$ could help to increase $\mathrm{H}_{2}$ yield and reduce $\mathrm{CO}_{2}$ yield substantially, which rose the calorific values of gases. Miller et al [6] studied SCWG of Spirulina in the absence of catalysts under the condition of $550-600{ }^{\circ} \mathrm{C}, 4-9$ s residence time, $25 \mathrm{wt} \%$ feedstock concentration and $23.5 \mathrm{MPa}$ and analyzed factorial experiments results. Notably, the reactor utilized was a plug flow reactor, different from common batch reactor. Thus, the residence time was very short (only several seconds) compared with usual reaction time (often several minutes). The results indicated that temperature and residence time had significant effects on gasification efficiency (GE) and gasification rate. A maximum gasification rate was obtained when $\tau \leq 2 \mathrm{~s}$, which could be due to the onset of turbulent flow as indicated by a high Reynolds number.

Chlorella. Chlorella is a green unicellular alga with low-lipid high-protein content, found in both fresh and marine waters usually [7] and it is also as food-grade material. Onwudili et al [5] researched SCWG of Chlorella vulgaris under the condition of $500{ }^{\circ} \mathrm{C}, 30 \mathrm{~min}$ reaction time, $36 \mathrm{MPa}$ and 15 wt $\%$ feedstock concentration in the presence/absence of $\mathrm{NaOH}$ and/or $\mathrm{Ni} / \mathrm{Al}_{2} \mathrm{O}_{3}$ and he found that the gas yield was $67 \%$ without $\mathrm{NaOH}$ and $\mathrm{Ni} / \mathrm{Al}_{2} \mathrm{O}_{3}$, which indicated that gas products were the dominant reaction products when no catalysts or only the nickel-catalyst was used. However, water-soluble products were the predominant reaction products and the gas yield was $24 \%$ with only $\mathrm{NaOH}$ used and $\mathrm{NaOH}$ and $\mathrm{Ni} / \mathrm{Al}_{2} \mathrm{O}_{3}$ used. Meawhile, composition of gases yielded was various with or without $\mathrm{NaOH}$ and/or $\mathrm{Ni} / \mathrm{Al}_{2} \mathrm{O}_{3}$. For Chlorella, $\mathrm{H}_{2}$ yield increased from $18.3 \mathrm{~mol} \%$ to $57.3 \mathrm{~mol} \%$ accompanied without $\mathrm{CO}_{2}$ yielded when only $\mathrm{NaOH}$ was used. Chakinala et al [8] investigated SCWG of Chlorella Vulgaris at varying operating conditions such as temperature $\left(400-700{ }^{\circ} \mathrm{C}\right)$, reaction time (1-15 $\mathrm{min})$, feedstock concentration $(2.9 \mathrm{wt} \%, 7.3 \mathrm{wt} \%)$ and the addition of catalysts $\left(\mathrm{Ru} / \mathrm{TiO}_{2}, \mathrm{NiMo} / \mathrm{Al}_{2} \mathrm{O}_{3}, \mathrm{P}_{\mathrm{t}} \mathrm{P}_{\mathrm{d}} / \mathrm{Al}_{2} \mathrm{O}_{3}, \mathrm{CoMo} / \mathrm{Al}_{2} \mathrm{O}_{3}\right.$, inconel powder, Ni wire). He observed that the dry gas composition of uncatalyzed gasification of Chlorella Vulgaris in SCWG mainly contained $\mathrm{CO}_{2}$, $\mathrm{CO}, \mathrm{CH}_{4}, \mathrm{H}_{2}$, and some $\mathrm{C}_{2}-\mathrm{C}_{3}$ compounds. The higher gasification efficiency (GE) needs higher temperatures, lower algae concentrations, and longer residence times and the highest GE was $84 \%$ at $600{ }^{\circ} \mathrm{C}$ and $2 \mathrm{~min}$ reaction time with nickel-based catalysts. Complete gasification required higher temperatures $\left(700{ }^{\circ} \mathrm{C}\right)$ and excess amounts of $\left(\mathrm{Ru} / \mathrm{TiO}_{2}\right)$ catalyst. He also demonstrated that adding catalysts could help to obtain higher yields of $\mathrm{H}_{2}$ and lower $\mathrm{CO}$ yields via enhanced water-gas shift activity. Minowa and Sawayama [9] performed experiments of Chlorella Vulgaris at low temperature $\left(350^{\circ} \mathrm{C}\right)$ in the presence of nickel catalyst and proposed a new method of cultivation of algae in the recovered solution obtained from the low-temperature (near critical) catalytic gasification of algae and they obtained a methane-rich gas with carbon conversion ranging between 35 and $70 \%$. Moreover, they also found all nitrogen in the microalga was converted to ammonia. Raheem et al [10] optimized SCWG of Chlorella vulgaris under varying conditions of temperature $\left(500-900{ }^{\circ} \mathrm{C}\right)$, microalgal (Chlorella vulgaris) biomass loading $(0.6-2.5 \mathrm{~g})$, heating rate $\left(5-25{ }^{\circ} \mathrm{C} / \mathrm{min}\right)$, and equivalent ratio (ER $=0.1-0.35$ ) via central composite design $(C C D)$. He also achieved a number of valuable results and he presented that temperature was the most significant process parameter influencing $\mathrm{H}_{2}$ production, followed by biomass loading and heating rate. The optimum $\mathrm{H}_{2}$ yield was 
$41.75 \mathrm{~mol} \%$ under the condition of $703{ }^{\circ} \mathrm{C}$, biomass loading of $1.45 \mathrm{~g}$, a heating rate of $22^{\circ} \mathrm{C} / \mathrm{min}$, and an ER of 0.29 .

Nannochloropsis. Nannochloropsis sp. is a marine algae with high-lipid content [11]. There are several studies about it. Guan et al [12] reported a systematic study of the gasification of Nannochloropsis sp. in supercritical water at $450-550{ }^{\circ} \mathrm{C}$. He found that the main gas production contained $\mathrm{H}_{2}, \mathrm{CO}_{2}$ and $\mathrm{CH}_{4}$ and lesser amounts of $\mathrm{CO}, \mathrm{C}_{2} \mathrm{H}_{4}$ and $\mathrm{C}_{2} \mathrm{H}_{6}$. Similarly with research about Chlorella, more rigorous reaction condition (including higher temperatures, longer reaction times, higher water densities, and lower algae loadings) favored higher gas yields. The feedstock concentration strongly affected the $\mathrm{H}_{2}$ yield, which more than tripled when the concentration decreased from $15 \mathrm{wt} \%$ to $1 \mathrm{wt} \%$. In addition, the water density had little effect on the gas composition. Guan et al [13] investigated the effect of catalyst Ru/C on SCWG of Nannochloropsis $s p$. at $410{ }^{\circ} \mathrm{C}$ and the gasification efficiency was only $45 \%$ at $75 \mathrm{~min}, 4.3 \mathrm{wt} \%$ feedstock concentration and a catalyst loading of $1 \mathrm{~g} / \mathrm{g}$ (mass of $\mathrm{Ru} / \mathrm{C}$ catalyst/mass of dry algal biomass). He proposed catalyst loading had the most significant effect on both the yields and composition of the gaseous products. When the catalyst loading reached $2 \mathrm{~g} / \mathrm{g}$, complete gasification of the microalga was achieved. Brown et al [14] converted Nannochloropsis sp. into gas production via SCW from 200 to $500{ }^{\circ} \mathrm{C}$ with $60 \mathrm{~min}$ in the absence of any catalyst and obtained the highest $\mathrm{H}_{2}$ yield was $39 \%$ at $400{ }^{\circ} \mathrm{C}, 5 \mathrm{wt} \%$ feedstock concentration. He also found that the major combustible gases were $\mathrm{H}_{2}$ and $\mathrm{CH}_{4}$, with smaller amounts of $\mathrm{C}_{2} \mathrm{H}_{4}$ and $\mathrm{C}_{2} \mathrm{H}_{6}$, similar with the research of Guan et al [15]. Furthermore, very little or no $\mathrm{CO}$ was presented during the temperature range, and it could be due to water-gas shift and/or methanation reactions strengthened.

Others. There are few research about other algae. Onwudili et al [5] considered Saccharina latissima as the feedstock of SCWG and found that the gasification efficiency was $65 \%$ without any $\mathrm{NaOH}$ and $\mathrm{Ni} / \mathrm{Al}_{2} \mathrm{O}_{3}$. Significantly, the gasification efficiency decreased to $12 \%$ and $14 \%$ with only $\mathrm{NaOH}$ used and $\mathrm{NaOH}$ and $\mathrm{Ni} / \mathrm{Al}_{2} \mathrm{O}_{3}$, respectively. However, $\mathrm{H}_{2}$ mole yield increased from $25 \%$ to $69 \%$ with the addition of $\mathrm{NaOH}$ and $\mathrm{Ni} / \mathrm{Al}_{2} \mathrm{O}_{3}$, accompanied with lower $\mathrm{CO}_{2}$ mole yield. Haiduc et al [16] investigated the influence of nickel on the growth of Phaeodactylum tricornutum, a trace contaminant that might accumulate upon effluent recycling. He proposed the existence of nickel adversely affected the growth of algae, and if the nickel concentration was $25 \mathrm{ppm}$, the cell division of algae could be inhibited completely. The gas production of SCWG of Phaeodactylum tricornutum with $\mathrm{Ru} / \mathrm{C}$ was methane-rich gas with gasification efficiency $(68-74 \%)$ and $\mathrm{C}_{1}-\mathrm{C}_{3}$ hydrocarbon yields of $0.2 \mathrm{~g}_{\mathrm{C} 1-\mathrm{C} 3} / \mathrm{g}_{\mathrm{DM}}$ (DM, dry matter). Tiong et al [17] studied SCWG of Scenedesmus quadricauda (low protein and high carbohydrate contents) at $385{ }^{\circ} \mathrm{C}, 15 \mathrm{~min}, 26 \mathrm{MPa}$ and $5 \mathrm{wt} \%$ feedstock concentration with or without nickel catalyst. He proposed that the yield could reach $80-90 \%$ with the catalyst but the one was only $12 \%$ in the absence of catalyst. For non-catalytic SCWG, the predominant gas product was carbon dioxide, which may be resulted from decarboxylation of algae. For catalytic $\mathrm{SCWG}$, the major gaseous products were $\mathrm{CH}_{4}, \mathrm{CO}_{2}, \mathrm{H}_{2}, \mathrm{CO}$ and its order of concentration was $\mathrm{CH}_{4}>\mathrm{CO}_{2}>\mathrm{H}_{2}>\mathrm{CO}$.

\section{Conclusion and future directions}

For algae feedstock, supercritical water gasification (SCWG) is a very potential technology for producing gases. As far as we're aware, it can offer efficient conversion from algae to gases, avoid water phase-changing heat dissipation and improve the recycling process of nutrients and metal elements, in favor of follow-up use of them.

Algae are composed of proteins, polysaccharides and lipids primarily. Different algae differ from percentage compositions of these three substances. Although some investigators have proposed proteins could be hard to gasification, it could be conquered via selecting appropriate reaction condition and catalysts. Therefore, different algae species may result in different optimal reaction parameters, gases yields, carbon gasification efficiencies and distributions of products. However, the 
research about SCWG of algae was few and this summary of SCWG of different algae can provide a research overview for further investigation in the very potential field with rapid development.

In the future, the research about the cell structure change of algae in SCW need to be studied more deeply. Various algae produce different compositions of solid and aqueous products, which may be necessary to quantify in follow-up separation processing for reasonably development and utilization. Moreover, the reaction kinetic research for feedstock and some intermediate products need to be devoted to the field to explore the reaction mechanism of SCWG completely.

\section{Acknowledgements}

This research was financially supported by China Postdoctoral Science Foundation (126540), Jiangsu Province Natural Science Foundation of China (BK20140406), National Natural Science Foundation (51406146) and Shaanxi Province Natural Science Foundation of China (2014JQ2081).

\section{References}

[1] Demirbas, A. 2001. Biomass resource facilities and biomass conversion processing for fuels and chemicals. Energy Conversion and Management, 42, 1357-1378.

[2] Savage, P. E. 1999. Organic chemical reactions in supercritical water. Chemical Reviews, 99, 603-621.

[3] Karayildirim, T., Sinag, A. \& Kruse, A. 2008. Char and Coke Formation as Unwanted Side Reaction of the Hydrothermal Biomass Gasification. Chemical Engineering \& Technology, 31, 1561-1568.

[4] Jena, U. \& Das, K. C. 2011. Comparative Evaluation of Thermochemical Liquefaction and Pyrolysis for Bio-Oil Production from Microalgae. Energy \& Fuels, 25, 5472-5482.

[5] Onwudili, J. A., Lea-langton, A. R., Ross, A. B. \& Williams, P. T. 2013. Catalytic hydrothermal gasification of algae for hydrogen production: Composition of reaction products and potential for nutrient recycling. Bioresource Technology, 127, 72-80.

[6] Miller, A., Hendry, D., Wilkinson, N., Venkitasamy, C. \& Jacoby, W. 2012. Exploration of the gasification of Spirulina algae in supercritical water. Bioresource Technology, 119, 41-47.

[7] Becker, E. W. 1994. Cambridge Studies in Biotechnology, Vol. 10. Microalgae: Biotechnology and Microbiology. Cambridge Studies in Biotechnology; Microalgae: Biotechnology and Microbiology. Cambridge University Press, The Pitt Building, Trumpington Street, Cambridge CB2 1RP, England; Cambridge University Press, 40 W. 20th Street, New York, New York 10011-4211, USA.

[8] Chakinala, A. G., Brilman, D. W. F., Van Swaaij, W. P. M. \& Kersten, S. R. A. 2010. Catalytic and Non-catalytic Supercritical Water Gasification of Microalgae and Glycerol. Industrial \& Engineering Chemistry Research, 49, 1113-1122.

[9] Minowa, T. \& Sawayama, S. 1999. A novel microalgal system for energy production with nitrogen cycling. Fuel, 78, 1213-1215.

[10] Raheem, A., Wan, A. W. A. K. G., Yap, Y. H. T., Danquah, M. K. \& Harun, R. 2015. Optimization of the microalgae Chlorella vulgaris for syngas production using central composite design. Rsc Advances, 5.

[11] Gouveia, L. \& Oliveira, A. C. 2009. Microalgae as a raw material for biofuels production. Journal of Industrial Microbiology \& Biotechnology, 36, 269-274. 
[12] Guan, Q., Savage, P. E. \& Wei, C. 2012a. Gasification of alga Nannochloropsis sp in supercritical water. Journal of Supercritical Fluids, 61, 139-145.

[13] Guan, Q., Wei, C. \& Savage, P. E. 2012c. Hydrothermal Gasification of Nannochloropsis sp with Ru/C. Energy \& Fuels, 26, 4575-4582.

[14] Brown, T. M., Duan, P. \& Savage, P. E. 2010. Hydrothermal Liquefaction and Gasification of Nannochloropsis sp. Energy \& Fuels, 24, 3639-3646.

[15] Guan, Q., Savage, P. E. \& Wei, C. 2012b. Gasification of alga Nannochloropsis sp. in supercritical water. The Journal of Supercritical Fluids, 61, 139-145.

[16] Haiduc, A. G., Brandenberger, M., Suquet, S., Vogel, F., Bernier-latmani, R. \& Ludwig, C. 2009. SunCHem: an integrated process for the hydrothermal production of methane from microalgae and $\mathrm{CO}_{2}$ mitigation. Journal of Applied Phycology, 21, 529-541.

[17] Tiong, L., Komiyama, M., Uemura, Y. \& Tien Thanh, N. 2016. Catalytic supercritical water gasification of microalgae: Comparison of Chlorella vulgaris and Scenedesmus quadricauda. Journal of Supercritical Fluids, 107, 408-413. 